\title{
Preparing them from home: A discourse on Christian parental responsibility towards ecological crisis
}

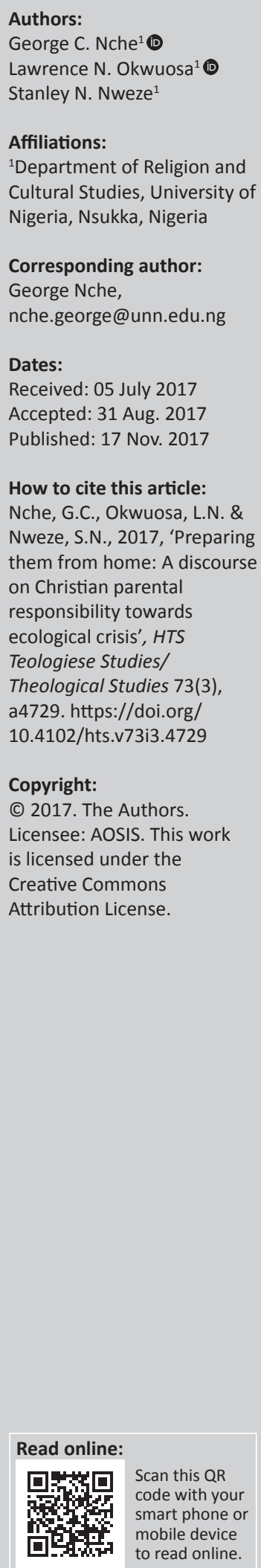

Few studies have discussed the roles of parents towards addressing ecological crisis. Yet, discourses on these roles have always been approached from a secular perspective. To this end, this paper critically discusses the roles of parents towards ecological crisis from the Christian or biblical perspective of their responsibilities towards their children. Using a hermeneutic phenomenological method of analysis, the article argues that ecological disasters of tomorrow could be prevented today through effective ecologically centred Christian parenting.

\section{Introduction}

It has been established that the world is threatened not only by the arms race, regional conflicts and continued injustices among peoples and nations but also by ecological crisis, which is mostly represented by climate change. The increasing depletion of the ozone layer and the related 'greenhouse effect' has now reached crisis proportions as a consequence of industrial growth, massive urban concentrations and vastly increased energy needs (John Paul II 1990). Indeed, climate change is now an existential issue and arguably one of the principal challenges facing humanity in our day (Pope Francis 2015; Romm 2016). In fact, the threats posed by climate change have set the international community the almost impossible dilemma of severely limiting the emission of greenhouse gases or facing the considerable risks associated with global temperature rise (Poortinga et al. 2011). At the moment, climate change is responsible for the dried up wells in Africa, floods in Asia that wash away crops and homes, wildfires in the United States and Russia, loss of villages and food species in the Arctic, environmental refugees and disease (Ackerman et al. 2013). Yet, it has been projected that there will be more cases of temperature extremes (such as heat waves and high intensity of rainfall) that would cause droughts, floods, famine, and diseases in many countries of the world (IPCC 2007).

This makes mitigation and adaptation imperative. Apart from policy-driven mitigating efforts both at the national and international levels by governments and non-governmental organisations, several scholars have recommended a focus on individual actions which, if performed in aggregate across the globe, can have a sizeable effect on reducing greenhouse gas emissions (Dietz et al. 2009; Vandenbergh, Gilligan \& Barkenbus 2008). As such, attempting to reduce emission by changing individual household and travel behaviours is a promising strategy. Parenting of children is one of the ways to achieve this at the household or family level as the profound influence of parenting practices on children's behavioural development and psychological wellbeing has been widely documented (see Eisenberg et al. 2001; Gershoff 2002; Halpenny, Nixon \& Watson 2010; Parke 2002; Smith et al. 2005).

Parenting is the process of utilising the knowledge and skills appropriate to planning for, creating, giving birth to, rearing and/or providing care for children (Morrison 1978). It also refers to purposive activities aimed at ensuring the survival and development of children (Clarke-Stewart 2006). Although the act of parenting seems to be generally instinctual to every parent, the need for effectiveness (Alvy n.d.) and commitment in carrying out the act can hardly be overemphasised. This is irrespective of who carries out such activity - whether biological or non-biological parents. Good and effective parenting is indeed invaluable to every human society. More so, it is also important to God. Hence, it is written in the Bible thus: 'Train up a child in the way he should go, and when he is old he will not depart from it' (Pr 22:6).

This article, therefore, attempts to discuss the role of parents in addressing the global ecological crisis from the Christian or biblical perspective of their responsibilities to their children. Hermeneutic phenomenology shall be used to achieve this objective. 


\section{The ecological crisis}

The global ecosystem is currently crisis-ridden with climate change at its vanguard. Describing this crisis, Nche (2012) wrote:

The sun that shone mildly to give the daylight has suddenly become hostile, harsh and unfavourable to man. The rain that dropped to give water to the earth, has also become hostile and extreme, destroying houses and lives. The ocean and seas that were initially calm and reserved have suddenly risen and encroaching into dry lands, flooding several places. The land that sustained and produced food for man has turned against man. (p. 73)

This is largely occasioned by uncontrolled human industrial activities. For over centuries, especially from the era of industrial revolution, humans have indulged in a culture of pollution, wastefulness and consumerism. Each year, hundreds of millions of tons of waste are generated, much of it non-degradable, highly toxic and radioactive, from homes and businesses, from construction and demolition sites, from clinical, electronic and industrial sources (Pope Francis 2015). This has continued till date and further exacerbated by the phenomenal advance of science and technology (Gnanakan 1999) without considerations of the limits to development (Arndt 1975). And it is in this culture that children are groomed. Hence, there have been successive generations of people who have continued to perpetrate this ecological injustice and profligacy.

This has currently brought enormous impacts on many societies of the world. For instance, climate change, which is at the vanguard of ecological crisis, has been reported to be responsible for crop failures and food scarcity, water crisis, increasing cases of diseases, economic downturn, infrastructural decay and dilapidation, mass displacement and migration, and death in many countries, especially in developing societies or countries in Africa and Asia (see Asoanya 2004; FAO 2016; Knox et al. 2012; Piao et al. 2010; Pope Francis 2015; Schlenker \& Lobell 2010; Sultan 2012; USEPA 2016; WHO 2008; Yohannes 2016) where children and women suffer disproportionately (Greenpeace n.d.; Lamble 2016; UNICEF 2015).

Yet, these impacts have been projected to increase in the future if climate change continues unmitigated or unabated (see: FAO 2016; IPCC 2007). This makes mitigation and adaptation imperative. ${ }^{1}$

One of the veritable media of achieving long term proenvironmental mitigating behaviour changes is through parenting at the household levels.

1.Mitigation in the context of climate change refers to anthropogenic intervention to reduce the sources or enhance the sinks of greenhouse gases (IPCC 2007). It entails using new technologies and renewable energies, making older equipment more energy efficient, or changing management practices or consumer behaviour. It can be as complex as a plan for a new city, or as simple as improvements to a cook stove design, protecting natural carbon sinks like forests and oceans, or creating new sinks design, protecting natural carbon sinks like forests and oceans, or creating new sinks through silvi culture or green agriculture [United Nations Environment Programm (UNEP) 2014]. It has however been stressed that even the most stringent mitigation efforts cannot avoid or eliminate further impacts of climate change in the next few decades, which makes adaptation essential, especially in addressing current and near-term impacts (IPCC 2007). Adaptation on the other hand, refers to the ability of a system to adjust to climate change in order to reduce its vulnerability an enhance the resilience to observe and anticipate the impacts of climate change.

\section{Christian concept of parenting}

The Christian concept of parenting draws from the principles of parenting as found in the Bible-Old and New Testament. There is a substantial number of verses that address issues concerning children in the Bible (Ex 20:12; 21:7-11; Deut 21:15-21; 24:1-4; Pr 1:8-9; 4 and 5; 6:20; (10:1; 13:1, 24; 17:21, $25 ; 19: 13,18,27 ; 20: 11 ; 22: 6,15 ; 23: 13-16,19-28 ; 28: 7,24 ; 29: 15$, 17:30:11, 17; Eph 5:21-33; 6:1-4; Col 3:18-21; Mt 19:8-12) These go to show how important children are to God and to humans as well. Psalms 127:3-5 reads:

${ }^{3}$ Sons are a heritage from the LORD, children a reward from him. ${ }^{4}$ Like arrows in the hands of a warrior are sons born in one's youth. ${ }^{5}$ Blessed is the man whose quiver is full of them. They will not be put to shame when they contend with their enemies in the gate.

Similarly, the importance of children is further portrayed in the incidence recorded in Matthew 19:13-14, which reads:

Then little children were brought to Jesus for him to place his hands on them and pray for them. But the disciples rebuked those who brought them. Jesus said, 'Let the little children come to me, and do not hinder them, for the kingdom of heaven belongs to such as these'.

These and more show how important children are to God and to parent. Unfortunately, children are however grossly omitted in theology. Botha (2016) has noted that:

It is a gross understatement to speak of the neglect of children in theology in general and in missiology in particular. As a matter of fact, children are quite conspicuous in their absence in the theology we write, even when such theology is purportedly aimed at the entire human race or the whole church. (p. 1)

It is only recently, that attempts are being made to factor children more and more into theological writing. Be that as it may, however, God's interest in the proper parenting, upbringing and welfare of children has been conspicuous. Hence, there are numerous verses as well as books (see Abott 2007; Gilbert 2011; MacArthur 1998; Swindoll 2014; Tripp \& Tripp 2008) that address parental responsibilities to children. Of these verses, Proverbs 22:6 appears to be a perfect example of what Christian parenting entails. This verse reads: 'Train a child in the way he should go, and when he is old he will not turn from it'. This verse has been subject to different interpretations. However, the best way to start is to understand the meaning from the original language Hebrew.

Proverbs 22:6 according to Swindoll (2014) contains only eight Hebrew words, each one packing a wealth of illustration and cultural analogy. The verb 'Train up' for instance, has the mingled ideas of 'dedicate', 'mouth' and 'make experienced'. 'A child' in Hebrew language is represented with the term 'na'ar' which refers to a little child, but it also refers to a man or woman of any age still living under a parent's roof or in the care of an authority figure. Then, the clause 'the way he should go' seems to carry the weight of the entire verse. According to Swindoll: 
The whole meaning of proverbs 22:6 turns on this phrase! We receive each child from the hand of God, not as a malleable lump of clay to be molded in whatever way we see fit but as a distinctive person with a destiny. We must honor God's creation of this one-of-a-kind individual by adapting our training to the child's way. (p.2)

From this view, it seems Swindoll believes that every child has a divine plan and destiny which is the way the child should be trained to go. This literary interpretation is also shared by Cohen (1965) who wrote:

In the way he should go (is interpreted to mean) according to his way. The intention is not the way of uprightness and good living but 'for the way in which he is to spend his life'. Whatever occupation he is later to follow it is necessary to prepare him for it in his early years, because then are habits formed which influence his conduct in manhood. (p. 146)

However, while it is important for parents to recognise or acknowledge that every child has a destiny or divine plan for his or her life, it should be noted that the phrase 'the way he should go' in its biblical or Old Testament context, which is the position of this paper, does not refer to the 'child's way' but 'God's way'. This is true because in the early Old Testament times, children were basically taught the laws of God. Religion and family life were woven together in the way parents brought up their children during this period (Alexander 1996). Hence, they were meant to learn by heart the laws of God and other parts of the Bible as well as encouraged to ask questions where they do not understand (see: Ex 13:14). For instance, places where God had done something special for this people were marked with large stones and when the children asked what they were for, the parents would explain (see: Jos 4:5-7). This idea is succinctly portrayed in the part ' $b$ ' of Ephesians 6:4, which reads: 'Fathers, do not exasperate your children, instead, bring them up in the training and instruction of the Lord.'

Be that as it may, the next clause in the verse which is 'when he is old' does not, in the words of Swindoll, mean 'one foot in the grave'. It rather means 'when he is mature'. It is also important to draw one's attention to the use of masculine pronoun 'he' in the verse, as though the female child is left out of this God-given injunction. The reason is that the early Old Testament society was a patriarchal and male-chauvinistic society. In a family structure, the father was the head of the family and had complete authority not just in practical matters but in religious ones, too. If he dies, his eldest son takes over by right of birth. Normally, only sons could inherit - and the eldest son in a family had a special position. Only if there were no sons could daughters inherit (Alexander 1996). This largely, albeit recently, explains why terms such as 'man' are used for all humanity (both man and woman) and 'he' for all gender (male and/or female) in the original Hebrew version of the Bible. In this light, therefore, one should know that the pronoun 'he' in this verse refers to both a male and/or a female child. Finally, the clause 'will not depart from it' has its key words as 'depart' whose equivalent in Hebrew language can be translated with 'to turn aside' (Swindoll 2014:5).
In all, Proverbs 22:6 gives a divine injunction to parents to train up children in the way they should go - basically in the knowledge or 'way of wisdom to live in the fear of God' (Maranville 2016). So that when they are grown, they will not depart from it. Training, as has been established, could mean giving instruction or educating the children. However, Mohler (2007) has contended that training involves more than instruction. It also includes living out our lives in front of our children, modelling godly morals. It includes giving children practice and correction to help them learn. It requires dedication on the part of parents. In fact, the whole focus of the verse, according to Mohler, is on the parent, not the child.

But, beyond the spiritual and moral import of Proverbs 22:6, the verse holds socio-cultural and political significance. It first of all portrays the important place good parenting occupies in the lives of individuals as well as in society. It further portrays the family as the fulcrum of society where foundations of individual lives are laid. Indeed, the family is the building block of society. A nation or culture is as strong and/or weak as the individual families that comprise that nation or culture (Gilbert 2011). This is why parents must take their parenting responsibilities seriously as the future of society depends on that. Good parenting could save a society from crime and other social ills. It could also save a society from ecological disasters. For instance, as the world is facing ecological crisis that is largely caused by human activities over the years, good and ecologically friendly parenting style could save societies from future or impending ecological disaster. This particularly can be achieved by following or adhering to some parenting principles that shall be discussed subsequently.

\section{Creation care: A divine mandate}

Creation care has been severally clamoured for in many ecological discourses. This is because of the depth of ecological crisis and its devastating impacts in many societies that have made creation care a matter of necessity. Beyond this, however, creation care is important to God and fundamental to Christian belief. Hence, after creation, God proclaimed that everything is very good (Gn1:31). Created in the image of God (Gn 1:26), humans were given dominion over all creatures (Gn 1:28) - a divine mandate that has divergently been interpreted and understood by theologians and scholars of different persuasions (see Isaacs 2013; Lewis 2013; Morris 2003). More so, this mandate has long been misunderstood and applied by humans who have grossly exploited and pillaged the earth. To this end, Pope Francis (2015) noted that:

Our insistence that each human being is an image of God should not make us overlook the fact that each creature has its own purpose. None is superfluous. The entire material universe speaks of God's love, his boundless affection for us. Soil, mountains; everything is, as it were, a caress of God. (pp. 49-50)

In a somewhat similar tone, Nche (2012) wrote that:

An aesthetic look at the waters and its inhabitants, the flowers, the plants and the trees; as well as a topographic analysis of the lands, well structured hills, mountains and fearful valleys; and a 
critical study of the processes that bring rain; as well as the various climatic seasons would show how beautiful, the earth is. (p. 76)

The earth is a divine gift and as such should be cherished and cared for. It was not beautifully made to be destroyed, but to be enjoyed and sustained by humans through a conscious stewardship over it. Leviticus 25:23-24 reads 'The land is mine and you are but aliens and my tenants. Throughout the country that you hold as a possession you must provide for the redemption of the land'. Indeed, creation care is a divine mandate and fulfils God's will. It is not just an option but a necessary way to evade the impending ecological disaster. Therefore, considering the current ecological need of the time, it becomes a matter of urgency that parents see 'creation care' as the way to go. Children should be trained to follow this way of creation care for futuristic purposes as the future seems gloomy and threatened by ecological disaster. How then can parents go about this? The principles or parenting styles that are discussed below answer this question.

\section{The styles of Christian parenting in the light of ecological realities}

The following are suggested styles of parenting children to be ecologically friendly. This could be represented in Figure 1.

\section{Re-telling the creation story in Genesis}

Storytelling is one of the fastest ways of instilling knowledge in children. It is not only instructive and informal, it makes them part of the narration. The story of the creation in the Book of Genesis makes for a good beginning in ecological education in the family. The crux of the whole story whether from Priestly (Gn 1:2:4a) or the Yahwist (Gn 2:4b-3) point of view is that creation is good. Creation did not take place on its own but through the divine will of God. Hence, creation is not for its own sake. It is channelled towards a divine purpose and thus must be treated as such. Again, God created the world and all that is in it (Ps 104:1) and saw that they are good (Gn1:25). Creation without any exception is good and must not be harmed or considered evil on its own.

Children should be meant to know that humans are part of creation and not above it. In fact, humans were created

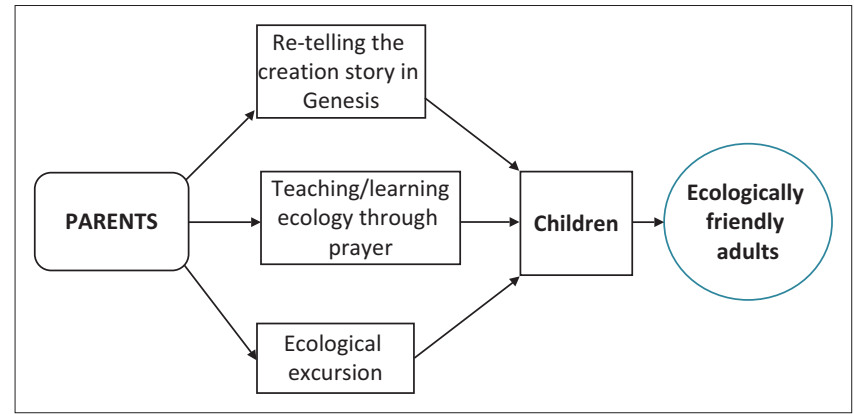

FIGURE 1: Showing a tripartite ecologically centred Christian parenting style. from the soil; hence, they are intrinsically part of the other creatures. Humanity is only distinct from other created things because they were created in the image and likeness of God and because they are to have dominion and subdue the earth (Gn 1:27-28). But this distinction places on them the responsibility which is exemplified in the human-given names of all the created beings (Gn 2:19). With these names, humans endear themselves to other created realities. On the other hand, the dominion mandate is not an invitation to use nature as a convenience. Rather, humans following the intention of God who is the primal creator are called to take care of all created realities. They are to show responsibility and accountability. Man is to work tirelessly to make sure that creation achieves its final goal, which is the glorification of God as the Psalmist suggests (Ps 148:7).

The story of Genesis is the story of the created family -the ecosystem. Any misbehaviour or action outside of the divine will would result in ecological crisis. This has been the bane of the world because humans misinterpreted their roles with regards to the environment. Indeed, it is because of human carelessness that the earth is bedevilled with uncontrolled climate change, air and water pollution, famine, earthquakes, desertification and deforestation.

Byre-telling this creation story to children, they will learn that if humans want a sustainable environment, they must care for nature in the manner of God who created all things. Humans are to see themselves as part of creation or else they would be injuring not only creation but also themselves. Example could be given in the person of Saint Francis of Assisi, who understood, embarrassed and lived in great harmony and communion with created realities. He did not just care for them but went as far as to call creatures, no matter how small, by the name brother or sister (Pope Francis 2015).

\section{Teaching and learning ecology through prayer}

The Lord's Prayer is the commonest prayer in Christendom. The prayer when closely looked at shows God's utmost involvement in created nature. In teaching his disciples this prayer, Jesus demonstrated that God takes care of all creatures' needs and guarantees their existence. Hence, Jesus taught of creatures' total dependence on God for their needs when he said in the Lord's Prayer: 'Give us our daily bread'. Although this was said in respect to humans alone, the welfare of other creatures was as well shown to be guaranteed especially in Biblical verses like Mathew 6:26 and Luke 12:24. It is the Creator who guarantees all creatures' welfare. On various occasions, Jesus elaborated on this by saying: 'Are not five sparrows sold for two pennies? And not one of them is forgotten before God' (Lk 12:6). 'Look at the birds of the air: they neither sow nor reap nor gather into barns, and yet your heavenly Father feeds them' (Mt 6:26):

Consider the lilies of the field, how they grow; they neither toil nor spin, yet I tell you, even Solomon in all his glory was not clothed like one of these. (Mt 6:28b-29) 
God loves and takes care of all his creatures and he makes his sun rise on the evil and on the good (Mt 5:45). It is God who takes care of all created things.

Because God is his creatures' sole provider, they should learn to totally depend and collaborate with him for their needs. It is this total dependence and collaboration with God for human needs that parents should inculcate in their children. They need to teach them that material success is not about domination and conquering of the material world. It is not about selfish acquisition, avarice, obsession, insatiability and greed for material things but about collaborating with God so that the world may really reflect his intention. God's intention has always been that humans use the created things with caution and a sense of responsibility. At the beginning of time, God prohibited human forebears, Adam and Eve, from eating from a specific tree with the consequence of death (Gn 2:16-17). He admonished the people of Israel after he gave them manna in the desert to take as much as they needed and nothing more and when some people kept more than they needed it became wormy and rotten (Ex 16:19-20).

Parents are thus obliged by their Christian faith to teach their wards contentment and the acceptance of the limits life imposes on them. Children must avoid excesses and wastes. Whatever does not immediately serve them is not needed and not for them; such belongs to others and the future generations. Humanity is to make good use of what it needs and with what it has build a responsible community. In this way, a genuine sense of the common good is established and maintained. This goes against the consumerist lifestyle, which Pope Francis says can only lead to violence and mutual destruction (Pope Francis 2015).

\section{Ecological excursion}

'Seeing is believing' has been one of the oldest methods of inculcating values. What people see tends to make an indelible impact on their subconscious and help form their world views. This becomes important in children's upbringing. Parents are bound to concretise their ideas and values to their children for easy assimilation and comprehension. This is what family excursions would guarantee in the inculcation of ecological values on children by parents.

Parents should make their children to know and appreciate their immediate environment. Knowing one's environment as part and parcel of one's life is the basic ecological education. This education includes knowing the plants, animals, historic places and natural phenomena like lakes, mountains and volcanoes in one's location with their accompanying medical, economical and aesthetic values. Ecological education evokes love and respect for nature.

To effectively do this, parents have to take their wards to markets where foodstuffs are sold or to zoos where animals are kept. A good ecological discussion could start with the creation and naming of all things by God. God created and knows everything by name even those human beings have not discovered. Furthermore, when God wanted to destroy the earth, He indirectly saved them all by asking Noah to put each of a kind into the Ark to safeguard them from destruction. This shows how invaluable they are to God and invariably to humanity. God did not save only Noah and his family but also plants and animals because human beings cannot survive without them. They are interior to human existence. In the words of Ignacimuthu (2010):

To live and act is to breathe the air, to drink some water, to eat fruits, roots, seeds, leaves, etc. We depend on minerals, plants, animals and these depend on the earth and the earth depends on a thousand cosmic, physical, chemical, magnetic factors and forces, processes and interactions. (p. 14)

So, parents should make it a point of duty to showcase the environments to their wards or children as precious things in the eyes of God and inevitable for authentic human existence. Likewise, they should teach environmental protection to their wards as part of divine ordinance for the sustenance of creation.

An effective ecological excursion and teaching by parents should translate to ecological praxis. It has to reflect the way people live their life and relate to other created things. Hence, a good parent-guided excursion to the zoo is a good opportunity to fight zoophobia. Parents would be expected to point out the different characteristics and importance of the animals in the ecosystem to their wards. In particular situations, local myths and fables concerning some of the animals may be narrated in order to buttress the point of human relationship with created nature. An excellent way to end an excursion to the zoo is for families to adopt an animal as pet. This would afford children the opportunity to remain in touch and develop likeness for these creatures.

On the other hand, a good grocery shopping would afford parents the opportunity to show their children the different vegetables and fruits that God created. It would be an opportunity to teach them how they contribute to human existence and thus should be cultivated by all. The way to end such an excursion would be to buy some seeds and start a little vegetable garden at the back of the house. The different stages in the development of the fruits and vegetables could be used by parents to teach their wards the different cycles of life.

\section{Conclusion}

So far, this article has attempted a discourse on parental responsibilities towards ecological crisis from the Christian or biblical perspective of their responsibilities towards their children. Beginning with the problem of ecological crisis, the paper highlighted the devastating impacts of climate change, which makes mitigation and adaptation imperative. Relying on already documented influence on children's wide-ranging development, parenting was proposed or discussed as a promising strategy in reducing emission by training or building pro-environmental behaviours in children at the family level. 
However, this position was situated within the Christian conception of parenting which emphasises dedication and commitment in the training of children as, for instance, implied in Proverbs 22:6. To this end, parents were enjoined to dedicatedly trained their children to embrace stewardship and care over creation, which is a divine mandate. Three basic ecologically centred parenting styles were suggested for Christian parents to employ in the training of children to become ecologically friendly adults in the future.

\section{Acknowledgements Competing interests}

The authors declare that they have no financial or personal relationships which may have inappropriately influenced them in writing this article.

\section{Authors' contributions}

G.C.N. conceived the idea or argument and wrote a substantial part of the manuscript. L.N.O. contributed in sharpening the idea or argument and wrote part of the manuscript. S.N.N. also contributed in refining the argument and wrote a part of the manuscript.

\section{References}

Abott, B., 2007, Biblical principles of parenting: A bible study guide workbook, viewed 21 August 2016, from www.newlifeob.org

Ackerman, et al., 2013, 'Evangelical scientists address to United States', viewed 01 August 2016, from www.eenews.net on

Alexander, P., 1996, The lion concise Bible encyclopedia, Lion Publishing, Sandy Lane West.

Alvy, K.T., n.d., What is effective parenting? Advocating, celebrating and promoting effective parenting and parenting education. The National Effective Parenting effective parenting and parenting education, The National Effective Par
Initiative, viewed 21 August 2016, from www. EfectiveParentingUSA.org

Arndt, H.W., 1975, 'Limits to development?', The Australian Quarterly 47, 79-89. https://doi.org/10.2307/20634787

Asoanya, A., 2004, The ecological crisis in Africa as a challenge to lasting cultural and sustainable development: A theological approach, European University Studies, Peter Lang, New York.

Botha, N., 2016, 'Children as theological hermeneutic: Is there a new epistemological break emerging?', HTS Teologiese Studies/Theological Studies 72(1), a3110. https://doi.org/10.4102/hts.v72il.3110

Clarke-Stewart, A., 2006, 'What have we learned: Proof that families matter, policies for families and children, prospects for future research', in A. Clarke-Stewart \& J. Dunn (eds.), Families count, pp. 321-336, Cambridge University Press, New York.

Cohen, A., 1965, Proverbs with Hebrew text, English translation and commentary, The Soncino Press, London.

Dietz, T., Gardner, G.T., Gilligan, J., Stern, P.C. \& Vandenbergh, M.P., 2009, 'Household actions can provide a behavioral wedge to rapidly reduce U.S. carbon emissions', Proceedings of the National Academy of Sciences of the United States of America 106, 18452-18456. https://doi.org/10.1073/pnas.0908738106

Eisenberg, N., Losoya, S. \& Fabes, R.A., 2001, 'Parental socialization of children's dysregulated expression of emotion and externalizing problems', Journal of Family Psychology 15, 183-205. https://doi.org/10.1037/0893-3200.15.2.183

Food and Agriculture Organisation (FAO), 2016, The state of food and agriculture: Climate change, agriculture and food security, Food and Agriculture Organization of the United Nations, Rome.

Gershoff, E., 2002, 'Parental corporal punishment and associated child behaviours and experiences: A meta-analytic and theoretical review', Psychological Bulletin 128 , 539-579. https://doi.org/10.1037/0033-2909.128.4.539

Gilbert, T., 2011, Parenting by the book, Rodgers Baptist Church Sunday School Series, viewed 26 August 2016, from http://rodgersbaptist.net/wp-content/ uploads/2012/05/06.-Biblical-Parenting.pdf

Gnanakan, K., 1999, God's world: A theology of the environment, Cambridge University Press, Cambridge.
Greenpeace, n.d., Human rights and the climate crisis: Acting today to prevent tragedy tomorrow, Briefing, viewed 03 January 2017, from www.ohchr.org

Halpenny, A.M., Nixon, E. \& Watson, D., 2010, Parents' perspectives on parenting styles and disciplining children, The National Children's Strategy Research Series, The Stationery Office, Dublin.

Intergovernmental Panel on Climate Change (IPCC), 2007, 'Summary for policymakers', in M.L. Parry, O.F. Canziani, J.P. Palutik, P.J. Van der Linden \& C.E. Hanson (eds.), Climate change 2007: Impacts, adaptation and vulnerability, pp. 1-976, Contributions of Working Group II to the Fourth Assessment, Cambridge University Press, Cambridge, UK.

Ignacimuthu, S., 2010, Environmental spirituality, St. Paul's, Bangalore.

Isaacs, D., 2013, 'Is there a dominion mandate?', Answers Research Journal 6, 1-16.

John Paul II, 1990, Message of his holiness Pope John Paul II for the celebration of the world day of peace, viewed 10 July 2016, from w2.vatican.va

Knox, J., Hess, T., Daccache, A. \& Wheeler, T., 2012, 'Climate change impacts on crop productivity in Africa and South Asia', Environmental Research Letters 7(3), 1-8. https://doi.org/10.1088/1748-9326/7/3/034032

Lamble, L., 2016, 'It's a disaster': Children bear brunt of Southern Africa's devastating drought', The Guardian, viewed 22 August 2016, from www.theguardian.com

Lewis, N., 2013, 'Does the genesis "Dominion Mandate" in Psalm 8 only relate to Jesus as divine Messiah?', Journal of Creation 27(1), 65-67.

MacArthur, J., 1998, Successful Christian parenting: Raising your child with care, compassion and common sense, Nelson Incorporated, Thomas, Edinburgh.

Maranville, C., 2016, 'Train up a child: What does Proverbs 22:6 mean?', viewed 26 August 2016, from www.lifehopeandtruth.com

Mohler, J.W., 2007, 'Proverbs 22:6 - A promise to parents?', viewed 22 July 2016, from www.magazine.biola.edu

Morris, H.M., 2003, 'The bounds of the dominion mandate', Institute for Creation Research (ICR), viewed 10 September 2016, from www.icr.org

Morrison, G.S., 1978, Parent involvement in the home, school and community, Merrill Publishing Company, Columbus, $\mathrm{OH}$.

Nche, G.C., 2012, 'Challenges of climate change: The role of Christian religious leaders', Journal of Educational and Social Research 10, 73-80.

Parke, R.D., 2002, 'Punishment revisited - Science, values and the right question: Comment on Gershoff (2002)', Psychological Bulletin 128, 596-601. https://doi. org/10.1037/0033-2909.128.4.596

Piao, S., Ciais, P., Huang, Y., Shen, Z., Peng, S., Li, J. et al., 2010, 'The impacts of climate change on water resources and agriculture in China', Nature 467, 43-51. https:// doi.org/10.1038/nature09364

Pope Francis, 2015, Laudato Si': Encyclical letter of the Holy Father Francis on care for our common home, Paulines Publications Africa.

Poortinga, W., Spence, A., Whitmarsh, L., Capsticks, S. \& Pidgeon, N.F., 2011 'Uncertain climate: An investigation into public skepticism about anthropogenic climate change', Global Environmental Change 21, 1015-1024. https://doi.org/ 10.1016/j.gloenvcha.2011.03.001

Romm, J., 2016, Climate change: What everyone needs to know, Oxford University Press, New York.

Schlenker, W. \& Lobell, D.B., 2010, 'Robust negative impacts of climate change on African agriculture', Environmental Research Letters 5, 1-8. https://doi.org/ 10.1088/1748-9326/5/1/014010

Smith, A.B., Gollop, M., Taylor, N.J. \& Marshall, K., 2005, The discipline and guidance of children: A summary of research, Children's Issues Centre and Office of the Children's Commissioner, Dunedin.

Sultan, B., 2012, 'Global warming threatens agricultural productivity in Africa and South Asia', Environmental Research Letters 7(4), 1-31. https://doi.org/ 10.1088/1748-9326/7/4/041001

Swindoll, C.R., 2014, 'Biblical parenting: Discovering your child and yourself (Proverbs 22:6)', viewed 01 August 2016, from www.insightworld.org

Tripp, T. \& Tripp, M., 2008, Instructing a child's heart, Shephard Press, Wapwallopen, PA.

UNICEF, 2015, Unless we act now: The impact of climate change on children, United Nations Children's Fund (UNICEF), New York, viewed 22 August 2016, from www. unicef.org

United Nations Environment Programme (UNEP), 2014, Climate change mitigation, viewed 22 June 2016, from www.unep.org

United States Environmental Protection Agency (USEPA), 2016, Climate impacts on agriculture and food supply, United States Environmental Protection Agency, viewed 04 January 2017, from www.epa.gov

Vandenbergh, M.P., Gilligan, J. \& Barkenbus, J., 2008, 'Individual carbon emissions: The low-hanging fruit', UCLA Law Review 55, 1701-1758.

World Health Organisation (WHO), 2008, Climate change and health, South-East Asian Advisory Committee Meeting (ACM), 1/7, 2(Rev.1), viewed 20 July 2016, from http://apps.who.int/iris/bitstream/10665/126809/1/SEA_ACM_Meet.\%20 $1 \_7.2 \% 20 \% 28$ Rev. $1 \% 29 . p d f$

Yohannes, H., 2016, 'A review on relationship between climate change and agriculture', Journal of Earth Science \& Climate Change 7, 335. 